ELTE BTK

\title{
A magyar Dosztojevszkij-kultusz Révay Mór János népmüvelö tevékenységének tükrében
}

Európai sajátosság, hogy a nagy válság-korszakokban mindig megnố a Dosztojevszkij-múvek iránti érdeklódés. Nem volt ez másképp Magyarországon sem, hiszen az elsố világháború utáni idôszakra, az 1920-30-as évekre tehetố az író népszerúségének a csúcsa. Vajon milyen egyedi folyamatok vezettek oda, hogy az orosz iró ekkorra a magyar kultúra szerves részévé vált? Jelen tanulmány többek között erre a kérdésre keres választ, és arra vállalkozik, hogy egyrészról feltérképezze a magyar Dosztojevszkijkultusz intézményi kereteit, másrészról bemutassa Révay Mór János népneveló tevékenységét, amely nagyban hozzájárulhatott ahhoz, hogy a magyar olvasóközönség megismerje Dosztojevszkij életét és megértse irodalomtörténeti jelentôségét.

\begin{abstract}
És ha alakjai nem is a mi körünkből valók, ha az a világ, amelyet munkáiban páratlan hüséggel megrajzol, nem is a mi világunk - az ő alkotásai éppen a felsorolt okoknál fogva nagy kultúrértékké válnak a magyarságra nézve is és összes müveinek orosz eredetiből való hủ és jó, müvészi forditása nagy gazdagodása a magyar irodalomnak is. (Révay, 1922. 43.)
\end{abstract}

D osztojevszkij magyarországi befogadástörténeről számos nóvummal szolgáló, különböző korszakokat összesítő munka született az 1990-es évek óta (Dukkon, 1991, 1992; Gedeon, 2011, 2013; Кроо, 2013; Ситар, 2013). Ezen tanulmányok zöme egyetért abban, hogy az 1920-30-as évekre tehető a Dosztojevszkij-kultusz magyarországi csúcsa, és abban sincs vita, hogy ennek elsősorban történelmi és eszmetörténeti okai vannak.

„....az irodalmi kultuszokban mindig erős a törekvés az élet esztétizálására. Ez elsősorban nem az élet széppé, hanem jelentésessé alakítását jelenti" - mondja Lakner Lajos (2005. 16.), és valóban: az első világháború utáni időszak válságai nem kerülték el a magyar szellemi életet sem, amely a háború borzalmait követő reményvesztettségében, az abból való kiútkeresésében szellemi kapaszkodóra lelhetett Dosztojevszkijben, azonosulhatott a problémavilágával, a müveinek (újra)értelmezése jelentéssel tölthette meg a lelkekben tátongó ürt. De vajon milyen egyéb körülmények vezettek oda, hogy a Dosztojevszkij-kultusz éppen az 1920-30-as években éri el Magyarországon a tetőfokát? Ennek a kérdésnek a megválaszolása azért is fontos, mert ,az utóélet egy adott 
szakaszának a vizsgálata egyúttal magának az életműnek a vizsgálata is" (Tverdota, 1998. 290.). Ebből a szempontból lényeges az 1921-es jubileum, mely alkalomból a magyar kulturális szcéna elismert alakjai (többek között: Juhász Gyula, Földi Mihály, Balázs Béla) ${ }^{1}$ emlékeznek meg az íróról különböző lapok hasábjain, ráirányítva a szélesebb közönség figyelmét e jeles évfordulóra. Emellett Dosztojevszkij személyét és élettörténetét körülvevő mítoszok is fenntartották az érdeklődést, elősegítetve a kultusszá válását. ${ }^{2}$ Ezek azonban csupán a legkézenfekvőbb magyarázatok.

A kultuszkutatás mai gyakorlatát leginkább az interdiszciplinaritás jellemzi, ennélfogva számos megközelítési mód áll a kutatók rendelkezésére. ${ }^{3}$ Mivel nem célom a magyarországi Dosztojevszkij-kultusz teljes rekonstrukciója (nem is volna lehetséges), csak egy szükebb mezejének a feltérképezésére vállalkoz(hat)om.

Jelen tanulmányt főleg történeti érdeklődés vezeti, területileg pedig leginkább a kultusz intézményi kereteit vizsgáló munkák sorába illeszthető be annak okán, hogy könyvkiadói szempontból közelíti meg a kultuszt. Abból a feltevésből indulok ki, hogy a magyar Dosztojevszkij-kultusz dinamikáját egyebek mellett jelentősen befolyásolta a könyvkereskedelem és az azt müködtető vállalatok tevékenysége. Lakner szerint „a kultusz a hivatásszerüen irodalommal vagy népneveléssel foglalkozók találmánya, s közülük kerülnek ki szervező-irányítói is”, de megjegyzi, hogy „a naiv és kultikus olvasók hozzájárulása és igénye nélkül, vagyis egy átfogó társadalmi elfogadottság nélkül e törekvések eredménytelenek lennének" (Lakner, 2005. 18.). Tehát mindkét szereplő (olvasó és könyvkiadó) igényére és szándékára kiterjedő folyamatról van szó, ennek ellenére a kultuszvizsgálódások nem túl gyakran vetnek számot a könyvkiadók szerepével, még úgy sem, hogy az olvasók általuk, rajtuk keresztül kapcsolódnak be az írói kultusz nagy egészébe.

Dosztojevszkij magyarországi recepciójával kapcsolatos kutatásaim ${ }^{4}$ során kitünt a Révai Irodalmi Intézet néven ismert kiadó, amely a 20. század elejére a magyar irodalmi és kulturális élet meghatározó szereplöjévé lépett elő. A Dosztojevszkij összes munkáinak jubileumi kiadásával, véleményem szerint, a kiadó nemcsak az életmühöz való hozzáférést biztosította, hanem nagyban hozzájárult az író alakját és müveit körülvevő kultusz fellendüléséhez, az olvasói réteg kiszélesítéséhez. Ebből fakadóan a továbbiakban ismertetek néhányat a kiadó projektjei közül azzal a céllal, hogy egyfelől rávilágítsak a Dosztojevszkij-kultusz korabeli kontextusára, másfelől rámutassak arra, hogy Dosztojevszkij müveinek sikere és népszerüsége nem csupán tanújele az író müvei iránti egyre növekvő érdeklődésnek vagy leképződése az amúgy javában zajló folyamatoknak. Ellenkezőleg: Révay-féle kiadványok hatással voltak a Dosztojevszkij-kultusz alakulására, s nemcsak táplálták azt, hanem formálták is az olvasóközönség értékítéletét, segítséget nyújtva az író szövegeinek mélyebb megismeréséhez és megértéséhez.

Dosztojevszkij születésének százéves évfordulója alkalmából 1921-ben a Révai Irodalmi Intézet - feltehetőleg Révay Mór, a vállalat akkori vezetőjének elgondolása alapján - megindította Dosztojevszkij összes munkái címen az író müveinek magyar kiadását. Nem meglepő, hogy ez a tekintélyes vállalkozás igazi irodalmi eseménnyé vált. Számos hírlap és folyóirat tudósított róla ${ }^{5} \mathrm{~s}$ volt köztük olyan is, amely Dosztojevszkijkülönszámban közölte a sorozat hírét. ${ }^{6}$ Ez a kiadás a legmagasabb igényeket is kielégítő, több szempontból is értékes vállalkozás volt, amelyről így ír maga Révay ${ }^{7}$ Mór a kiadó elöszavában:

Lelkiismeretes kiadónak soha még annyi megfontoltsággal, annyi gondossággal és körültekintő bírálattal nem kellett megválogatnia azt, a mit a magyar közönségnek nyújtani akar, a mit annak nyújtani szabad - mint a mai időben. [...] Melyik az az olvasmány, mely megfelel a mai magyar léleknek, minő az az irodalom, mely még hatni képes rá, minő az a szellem, mely megfogja lelkületét, melyik az az 
ige, mely páratlan megcsalódottságában még bizalmat kelt benne, melyik megnyilatkozása az emberi szellemnek képes az emberiségbe vetett és elveszett hitét még esetleg helyreállítani. A nagy világégés, mely még el sem mult teljesen, egyetlen nemzetet sem sújtott annyira, mint a magyart. És egyetlen nemzet sincs annyira ráutalva a lelki megújhodásra, mint a magyar. Ennek a világégésben álló kornak első meglátója a nagy orosz író, Dosztojevszkij volt és ő volt az, a ki nemcsak megjövendölte az elkövetkezendöket, de feltárta a megoldásokat is... (Révay, 1921)

Révay írása a kultikus megközelítés klasszikus példája, s nemcsak érdekes adalék Dosztojevszkij magyarországi recepciótörténetéhez, de a háború utáni társadalom lelki, szellemi állapotának és igényeinek a lenyomata is. Továbbá kirajzolódik belöle a sorozat elindítása mögött rejlő szándék, amely meszsze túlmutat üzleti célokon, hiszen a kiadó elgondolása az, hogy ezekben a remény és kilátás nélküli időkben kapaszkodót nyújtson az olvasóknak Dosztojevszkij müvei és hősei által.

A fordítások zömét Szabó Endre készítette, - akinek az orosz irodalmat, különösképp Dosztojevszkijt népszerüsítő tevékenysége ismert a ruszisták körében (Zöldhelyi, 1961) - s bár egy része korábban már megjelent, ${ }^{8}$ több új fordítás éppen a Dosztojevszkij-öszszesnek köszönhetően valósult meg (például A Karamazov testvérek, ${ }^{9}$ az Emlékiratok a holtak házából, ${ }^{10}$ A kamasz, ${ }^{11}$ a Golyadkin úr hasonmása $\left.{ }^{12}\right)$, a színvonalukat dícsérik sajtóban és magánlevelekben egyaránt, ${ }^{13}$ ráadásul az egyes kötetek tartalmazzák a kor legelismertebb szakembereinek bevezető tanulmányait, amelyek amellett, hogy Dosztojevszkijt behatóan értelmezik, mélyen személyes élményekről tanúskodnak, betekintést nyújtva a századelő szellemi elitjének Dosztojevszkij-befogadásába. Figyelemreméltó módon elevenítette meg Dosztojevszkij emberi alakját, műveinek világát Földi Mihály, Kárpáti Aurél és Kuncz Aladár. Benedek Marcell a rá jellemző egyszerüséggel és érzékenységgel mutatta ki (már akkor!) a dosztojevszkiji fantasztikum sajátosságait, segítve a laikus olvasót az író esztétikai és poétikai univerzumának a megismerésében, míg Juhász Andor a művészi szemlélet mellett a komikum eredetét és jellemzőit vizsgálta, az orosz lélekábrázolás irodalmi hagyományának tükrében. Schöpflin Aladár ezzel szemben a társadalmi proplémák felöl közelítette meg Dosztojevszkij-szövegek müfaji és filozófiai kérdéseit, a női szerzők pedig, N. Apáti Jolán és Ritoók Emma személyében, a lélektani mélységét tárták fel. ${ }^{14}$
A fordítások zömét Szabó Endre készítette, - akinek az orosz irodalmat, különösképp Dosztojevszkijt népszerüsitó tevékenysége ismert a ruszisták körében (Zöldhelyi, 1961) - s bár egy része korábban már megjelent,8 több új fordítás éppen a Dosztojevszkij-összesnek köszönhetốen valósult meg (például A Karamazov testvérek,9 az Emlékiratok a holtak házából,10 A kamasz, a Golyadkin úr hasonmása), a szinvonalukat dícsérik sajtóban és magánlevelekben egyaránt, ráadásul az egyes kötetek tartalmazzák a kor legelismertebb szakembereinek bevezetó tanulmányait, amelyek amellett, hogy Dosztojevszkijt behatóan értelmezik, mélyen személyes élményekról tanúskodnak, betekintést nyújtva a századeló szellemi elitjének Dosztojevszkijbefogadásába. 
Ez a kiadás ${ }^{15}$ tehát annyi új ismerettel, szemponttal gazdagította az olvasókat - akik a 20. századig csupán az első nagyregényével és annak hősével, Raszkolnyikovval azonosították Dosztojevszkijt -, hogy vitathatatlanul hozzájárult ahhoz, hogy tágabb perspektívából értelmezhessék az író életművét. Ezért sem gátol(hat)ta Dosztojevszkij növekvő kultusza szövegeinek esztétikai befogadását, nem fed(het)te el magukat az alkotásokat.

A Dosztojevszkij-összesnek vannak olyan előzményei, melyekböl kiviláglik az a szellemiség, amely kezdetektől fogva jellemezte a Révai Irodalmi Intézetet és megadta a müködésének irányát, lehetővé téve azt, hogy jelentős és (irodalom- és kultúrtörténeti szempontból is) elismerésre méltó kezdeményezések sora valósuljon meg. E szellemiség mögött Révay Mór János (1860-1926) állt, aki igen komolyan vette kiadói tevékenységének a társadalomra és a kultúrára gyakorolt szerepét, az irodalom társadalmi integrációját tüzve ki feladatául.

A Dosztojevszkij-sorozat kiadása idején Révay Mórnak már jelentős tapasztalata volt szépirodalmi vállalkozások terén. 1880-ban lépett be az apja, Révai Sámuel által vezetett könyvkereskedésbe, ${ }^{16}$ majd megalapította a kiadói osztályt. Az első nagyszabású és sikeres projektje a Regényvilág szépirodalmi folyóirat-sorozat volt, amely elöször a Regényvilág. Magyar Családi Regénytár a müvelt közönség számára címet viselte (Révay, 1920. 1/49.). Révay a kezdetektől fogva a regény müfajára fókuszált, és elszántan hitt abban, hogy ezzel a felvilágosító vállalkozással fontos társadalmi problémákat old meg. A napilapok népszerüsége és gyors fejlödése miatt háttérbe szorultak a nagy terjedelmü müvek. Az írók, alkalmazkodva a napi sajtó igényeihez, novellákra és esszékre „pazarolták” erejüket és tehetségüket. A könyvirodalom, amely az 1867-es osztrák-magyar kiegyezés után az autonómia növekedésével rohamos fejlődésnek indult, ekkorra szinte eltünt, évente csak néhány szépirodalmi mü jelent meg önálló könyvként. Révay egy olyan olcsó regény-folyóiratot álmodott meg, ami csökkenti az előállítás költségeit, bővíti az olvasók és előfizetők körét és képes bevonzani a kor jeles íróit. A Regényvilággal tehát az írók helyzetén is kívánt változtatni, s hogy megvalósítsa ezt a nagyléptékü - a könyvkereskedelem helyzetének fényében pedig egyenesen merésznek tünő - elképzelését, az alig húszéves fiatalember ismeretlenül beállított Jókai Mórhoz, a korszak legnagyobb, mondhatni, a „legkultikusabb" írójához abban a reményben, hogy a nemes cél ismeretében az beleegyezik a sorozatindító regény megírásába. Jókai még aznap rábólintott (bővebben ld. Révay, 1920. I/51-53.), és 1880-ban elindulhatott a Regényvilág sorozat, melynek ötéves fennállása alatt 25 magyar és ugyanennyi külföldi regény látott napvilágot. E sorozatnak köszönhető, hogy az olvasók - akik addig Dosztojevszkijt kizárólag kisprózai müvek révén ismerték (Rejtő, 1961. 296.) - felfedezhették a regényíró Dosztojevszkijt, a Megalázottak és megszomoritottak által, amely az 1885 . évfolyamban jelent meg, Fáy J. Béla fordításában (A szenvedők címmel).

1895-ben, amikor a Révai Testvérek Irodalmi Intézet Rt. megalakult, Révay Mór lett a vezérigazgató. Irányítása alatt rohamos fejlődésnek indult a cég, mely egyszerre kiadói, nyomdai és terjesztői tevékenységet is folytatott. Révay ebben az időszakban számos szépirodalmi és tudományos sorozatot álmodott és valósított meg, ${ }^{18}$ melyek közül a Klasszikus Regénytár címü sorozat az, ami leginkább tükrözi irodalom(és Dosztojevszkij-) felfogását, és betekintést nyújt abba a munkafolyamatba, amely megalapozta a Dosztojevszkij-összes kiadását. ${ }^{19}$

A Klasszikus Regénytárt Ambrus Zoltán és Voinovich Géza szerkesztették, és az első kiadásban (1904-1910), mely 57 kötetet tartalmazott, Dosztojevszkij két regénye jelent meg: 1904-ben a Bün és bünhödés, 1910-ben A félkegyelmü, mindkettő Szabó Endre fordításában. Ezeket megjelentetik újra a második, 22 kötetes kiadásban (1919-1920) is, de tovább bővítik a repertoárt: 1919-ben jelenik meg először a Szegény emberek Trócsányi Zoltán fordításában, 1920-ban pedig a Megalázottak és megszomoritottak, Szabó Endre újrafordításában. A sorozat szerkesztői gondoskodtak a minőségi magyar szövegekről 
(Faludi, 1941), melyek mindegyike eredeti müvekből készült, kiváló műfordítók által. Gondjuk volt továbbá a regények elé írandó bevezetésre, amely megismertette az olvasót az írók életrajzával és munkásságával. A sorozat nem hozott anyagi sikert (Révay, 1920. 2/155.), de erkölcsi értelemben mindenképpen nyert a vállalat, többek között a pozitív kritikai fogadtatásnak köszönhetően, irodalmi és kultúrtörténeti jelentőségét évtizedekkel később is méltatták. ${ }^{20}$

Ez a gyakorlat érvényesült a Dosztoejvszkij összes munkái szerkesztésénél is, amely kétségkívül az író kultuszának egyik fontos állomása (ha nem is éppen kiindulópontja). Keletkezése a kiadói feladatkörök sajátos értelmezéséből fakad, és a hátterét, mint láttuk, nem kizárólag a jubileumi év kínálta üzleti lehetőség alkotja. ${ }^{21}$ A bemutatott vállalkozások mögött felsejlik Révay Mór érzékeny személyisége, az irodalomról és annak szerepéről alkotott nézetei, amelyek meghatározták a saját kiadói tevékenységét és számottevően befolyásolták egy egész iparágnak a szemléletét. ${ }^{22}$ Mindezt, úgy gondolom, érdemes tekintetbe venni a magyarországi Dosztojevszkij-kultusz valódi arányainak a megállapításához.

\section{Bibliográfia}

Dukkon Ágnes (1991). Véletlen hasonlóság vagy szellemi rokonság? Érintkezési pontok Dosztojevszkij dialektikájának bahtyini koncepciójában és Vatai László református teológus értelmezésében. Confessio, 4, 60-68.

Dukkon Ágnes (1992). A két világháború közötti magyar Dosztojevszkij-kultusz szellemi háttere. Protestáns Szemle, 4, 258-270.

Füst Milán (1921). Szabó Endre fordításairól. Nyugat, 6. https://epa.oszk.hu/00000/00022/00289/08802.htm Utolsó letöltés: 2021. 02. 17.

Faludi István (1941). Ambrus Zoltán elbeszélő müvészete. Ahenaeum.

Gedeon Sarolta (2015). Dosztojevszkij-művek magyarországi recepciótörténetének rövid áttekintése a 20. század válságkorszakaiban. In Bene Sándor \& Dobos István (szerk.), Válság és kultúra: a doktoriskolák IV. nemzetközi magyarságtudományi konferenciájának elöadásai. Budapest, 2013. augusztus 22-23. Nemzetközi Magyarságtudományi Társaság. 267-278.

Gedeon Sarolta (2011). Dosztojevszkij magyarországi recepciótörténete 1945-1958 között. Filológia, 2(3-4), $135-150$

György Lajos (1946). A magyar és az orosz irodalom kapcsolatai. Erdélyi Múzeum-Egyesület. DOI: $10.36240 /$ etf-200

Kalavszky Zsófia (2010). Az irodalmi kultuszkutatás lehetőségei az orosz kultúrakutatások perspektívájából: Az irodalmi kultuszkutatás a mai Oroszországban. In Berkes Tamás (szerk.), Borostyánút: Tanulmányok Bojtár Endre 70. születésnapjára. Reciti. 81-93.

Kalavszky Zsófia (2015). Az életrajzi legenda mint az írói kultuszok életképességének egyik biztosítéka. Vázlat egy lehetséges szemiotikai vizsgálathoz. In Jeney Éva \& Kálmán C. György (szerk.), „Inkább figyeld talán az irodalmat”. Írások Veres András 70. születésnapjára. Reciti. 19-24.

Kókay György (1997). A könyvkereskedelem Magyarországon. Balassi Kiadó.

Lakner Lajos (2005). Irodalmi kultusz, történetiség, aktualitás. A kultuszkutatás útjain. In Kalla Zsuzsa, Takáts József \& Tverdota György (szerk.), Kultusz, mü, identitás. Kultusztörténeti tanulmányok 4. A Petőfi Irodalmi Múzeum Könyvei 13. PIM. 11-30.

Rejtő István (1961). Dosztojevszkij Magyarországon (1850-1945). In Kemény G. Gábor (szerk.), Tanulmányok a magyar-orosz irodalmi kapcsolatok történetéböl II. Akadémiai Kiadó. 293-339.

Révay Mór János (1920). Írók. Könyvek. Kiadók. Egy magyar könyvkiadó emlékiratai I-II. Révai Testvérek Irodalmi Intézet Rt.

Révay Mór János (1921). Kiadó előszava. In Dosztojevszkij, F. M., Karamazov testvérek I. Ford.: Szabó Endre. Dosztojevszkij összes munkái I-III. Révai-kiadás.

Révay Mór János (1922). Dosztojevszki magyarul. Szivárvány, 2(2/3). Dosztojevszki-szám. 41-43.

Schöpflin Aladár (1926). Révai Mór János. Nyugat, 14. https://epa.oszk.hu/00000/00022/00399/12365. htm Utolsó letöltés: 2021. 02. 11

SzabóEndre(1921). Voltaireés Dosztojevszkij.Nyugat, 21. https://epa.oszk.hu/00000/00022/00304/09232. htm Utolsó letöltés: 2021. 02. 11.

Széchenyi Ágnes (2016). Az orosz (b)irodalom recepciója Magyarországon. In Frank Tibor (szerk.), Az orosz birodalom születései. Magyar kutatók az egyetemes történelemröl. Gondolat. 345-370. 
Takáts József (2005). A tér és az idő nemzetiesítése és az irodalmi kultuszok. In Kalla Zsuzsa, Takáts József \& Tverdota György (szerk.), Kultusz, mü, identitás. Kultusztörténeti tanulmányok 4. A Petőfi Irodalmi Múzeum Könyvei 13. PIM. 46-55.

Trócsányi Zoltán (1940). Sorozatok elvirágzása. Magyar Könyvszemle, 4. http://real-j.mtak.hu/2588/1/ MagyarKonyvszemle_1940.pdf Utolsó letöltés: 2021. 02. 27.

Tverdota György (1998). A komor föltámadás titka. A József Attila-kultusz születése. Irodalomtörténet, 29/79(1-2), 289-298.

Újvári Péter (1929, szerk.). Magyar Zsidó Lexikon. https://mek.oszk.hu/04000/04093/html Utolsó letöltés: 2021. 01. 28.

Zöldhelyi Zsuzsa (1961). Szabó Endre, az orosz irodalom magyar népszerüsítője. In Kemény G. Gábor (szerk.), Tanulmányok a magyar-orosz irodalmi kapcsolatok köréböl II. Akadémiai Kiadó. 138-200.

Банченко, А. (2018). К вопросу теории культа Достоевского. In Кроо К., Бона Е. (szerk.), Голоса русской филологии из Будапешта. Литературоведение и языкознание на Кафедре русского языка и литературы Университета им. Лоранда Этвеma. ELTE Eötvös Kiadó. 7-19.

Кроо, К. (2013). Достоевский в венгерских литературоведческих исследованиях (1970-2012 гг.). Достоевский. Материаль и исследования 20. Нестор-история. 88-118.

Ситар, К. (2013). Между Востоком и Западом: восприятие Достоевского в Венгрии (по страницам журнала «Нюгат»). Достоевский. Материаль и исследования 20. Нестор-история. 405-419.

\section{Jegyzetek}

${ }^{1}$ Ld. Juhász Gyula (1921). A százesztendős Dosztojevszkij. Szeged, november 12., 262. sz.; Földi Mihály (1921). Száz éves Dosztojevszkij. Magyar Írás, 1921. június, 3. sz.; Balázs Béla (1922). Dosztojevszkij évfordulójára. Tüz. 130-131.

${ }^{2}$ Az írói biográfia és kultusz kapcsolatáról ld. Kalavszky, 2015.

${ }^{3}$ A hazai irodalmi kultuszkutatások interdiszciplinaritására mutat rá Takáts József is: „,...az irodalmi kultuszok kutatói - az esetek többségében - olyan anyaggal dolgoznak, ami túlvisz az irodalomtudomány szokványos határain, olyan társtudományok közegébe, mint a nacionalizmuselméletek, az emlékezetkutatás, a politikai cselekvések antropológiája vagy az etnikai földrajz, amelyekben a kultuszkutatáshoz hasonló vizsgálódások zajlanak már régebb óta, amelyekhez csatlakozni lehet vagy éppen tanulni tőlük" (Takáts, 2005. 46.); elméleti hátterét és módszereit emellett külföldi kutatások is gyarapítják. Jó példa erre Kalavszky Zsófia 2010-es tanulmánya, amely az oroszországi kultuszvizsgálódások módszereit ismerteti. Azonban meg kell jegyezni, hogy nem gyakoriak a Dosztojevszkij-kultusz problémájával, specifikumaival és történetével foglalkozó szakmunkák. A kevés kivételek egyike (Dukkon Ágnes munkái mellett) Banchenko Alexandra 2018-ban megjelent tanulmánya, amely Dosztojevszkij példáján keresztül vizsgálja az irodalmi kultusz elméleti hátterét (Банченко, 2018).

${ }^{4}$ Dosztojevszkij magyarországi recepciótörténetét vizsgáló orosz-magyar (Tomszki Müszaki Egyetem - ELTE) kutatási csoport résztvevőjeként kezdtem el foglalkozni a magyar befogadástörténet irodalmi-társadalmi hátterével, és jutottam el az írói kultusz kérdéséhez, amely számos új kutatási szemponttal gyarapítja az (elsősorban) irodalomtörténeti vizsgálódásainkat (Pályázat címe: Этапы и проблемы рецепции творчества Ф.М. Достоевского в венгерском культурном контексте / F. M. Dosztojevszkij magyarországi recepciótörténetének állomásai és problémái a magyar kulturális kontextusban. Pályázat szama, támogatói: 19-512-23008 РЯИК а; Проект фундаментальных исследований при поддержке РФФИ и фонда «За русский язык и культуру в Венгрии» в рамках программы повышения конкурентоспособности ТПУ / Alapkutatási projekt az Orosz Alapkutatásért Alapítvány és az „Az orosz nyelvért és kultúráért Magyarországon” alapítvány támogatásával, a Tomszki Müszaki Egyetem versenyképességi és kiválósági program keretében).

${ }^{5}$ A Nyugatban ez alkalomból Szabó Endre írását közlik: „Dosztojevszkij M. Tivadar 1821. október 30-án (a mi kalendáriumunk szerint november 12-én született). Ennek tehát most éppen száz esztendeje. Ezt a száz-éves fordulót mink, magyarok is megünnepeljük: a Révai Testvérek kiadják az én fordításomban a nagy regényíró összes műveit: Ebből a nagy kiadásból most van sajtó alatt a »Karamazov testvérek« címü nagyhírü és igen terjedelmes regény." (Szabó, 1921).

${ }^{6}$ Ilyen például a Szivárvány című folyóirat Dosztojevszkij-különszáma (1922/2-3. sz.), ahol több érdekes és személyes anyag mellett (levelek, visszaemlékezések) helyet kapott Révay Mór cikke is a Dosztojevszkij összes müvei kiadásának okairól és körülményeiről (a cikk részben megyegyezik a gyüjteményben közölt kiadói előszóval, melyböl idézünk). 
${ }^{7}$ Révay Mór János nevét saját életrajzi kötete alapján „,y”-nal, míg a kiadó, illetve édesapja nevét forrásoknak megfelelöen „i”-vel írom.

${ }^{8}$ A Bün és bünhödést például az első (1888, Singer-Wolfner kiadó) és a sorozatbeli megjelenése (1926) között hatszor (!) adták ki.

${ }^{9} \mathrm{Az}$ első fordítást Timkó Iván készítette, és 1888-ban jelent meg a Pesti Hirlapban, de olyannyira nem volt visszhangja, hogy később még kiadót sem talált rá. 1895-ben $A$ Hét adja ki a regény egy részét - A Nagy Inkvizitort - anonim fordításban, 1919-ben pedig a Magyar Szó című kolozsvári lap jelenteti meg Tabéry Géza és Dér Iván fordításában. Vagyis önálló könyvként - egyúttal a Dosztojevszkij-összes nyitódarabjaként - 1921-ben jelenik meg először.

${ }^{10}$ Elöször 1890-ben jelent meg a Képes folyóiratban, anonim fordításban, Egy halottasház emlékeiböl. A szibériai számüzöttek sorsa, regényrészlet címmel, majd 1897-ben az Athenaeum kiadó adta ki Timkó Iván fordítását Egy halottas-ház emlékiratai címmel.

${ }^{11}$ 1922-ben jelent meg az első magyar fordítás, amit Trócsányi Zoltán készített $A$ siheder cím alatt, és a Genius kiadó adta ki $A$ regényirás müvészei sorozat keretein belül.

${ }^{12}$ Szintén 1922-ben, s ugyancsak Genius kiadó gondozásában jelent meg Trócsányi Zoltán fordítása $A$ kétéltü Golyadkin címmel.

${ }^{13}$ Füst Milán így ír Szabó fordításairól: „Nem tudok ugyan oroszul - s mégis szívem-lelkem az orosz íróké s az orosz népé - melyet szeretni és csodálni ők tanítottak meg. Ez az irodalom az én szívem irodalma, s hogy ez lehetséges: azt itt most Szabó Endrének köszönöm meg! [...] Csak aki maga is kitünő író - csak az tud így fordítani, mint ő." (Füst, 1921)

${ }^{14}$ Bevezető tanulmányok a megjelenés sorrendjében:

Földi Mihály (1921). A „Karamazov testvérek”. In Dosztojevszkij, F. M., Karamazov testvérek I. Ford.: Szabó Endre. Révai-kiadás. (Dosztojevszkij összes munkái I-III.) 5-36.

Benedek Marcell (1922). Golyadkin úr hasonmása. In Dosztojevszkij, F. M., Golyadkin úr hasonmása. Ford.: Szabó Endre. Révai-kiadás. (Dosztojevszkij összes munkái IV.) 1-7.

Schöpflin Aladár (1923). A „Megmételyezettek”. In Dosztojevszkij, F. M., Megmételyezettek I-II. Ford.: Szabó Endre. Révai-kiadás. (Dosztojevszkij összes munkái V-VI.) 1-7.

Kárpáti Aurél (1923). Emlékiratok a holtak házából. In Dosztojevszkij, F. M., Emlékiratok a holtak házából. Ford.: Szabó Endre. Révai-kiadás. (Dosztojevszkij összes munkái VII.) 1-8.

Földi Mihály (1924). A „Játékos”. In Dosztojevszkij, F. M., A játékos. Ford.: Szabó Endre. Révai-kiadás. (Dosztojevszkij összes munkái VIII.) 1-32.

N. Apáti Jolán (1925). Dosztojevszkij, a pszichológus. In Dosztojevszkij, F. M., Nyetocska Nyesvanova. Ford.: Szabó Endre. Révai-kiadás. (Dosztojevszkij összes munkái IX.) 1-16.

Juhász Andor (1925). Az ifjú Dosztojevszkij. In Dosztojevszkij, F. M., Fehér éjszakák. Ford.: Szabó Endre. Révai-kiadás. (Dosztojevszkij összes munkái X.) 1-8.

N. Apáti Jolán (1926). Raszkolnyikov problémája. In Dosztojevszkij, F. M., Bün és bünhődés. Ford.: Szabó Endre. Révai-kiadás. (Dosztojevszkij összes munkái XI-XII.) 1-20.

Juhász Andor (1927). Vidám Dosztojevszkij. In Dosztojevszkij, F. M., A nagybácsi álma. Ford.: Szabó Endre. Révai-kiadás. (Dosztojevszkij összes munkái XIII.) 1-15.

N. Apáti Jolán (1927). Dosztojevszkij szerelmi élete és az „örök férj”. In Dosztojevszkij, F. M., Az örök férj. Ford.: Szabó Endre. Révai-kiadás. (Dosztojevszkij összes munkái XIV.) 1-20.

Munkácsy Mihály (1927). Dosztojevszkij, mint a nagyváros költője. In Dosztojevszkij, F. M., A nagyváros homályából. Ford.: Szabó Endre. Révai-kiadás. (Dosztojevszkij összes munkái XV.) 1-20.

Kuncz Aladár (1928). Dosztojevszkij miszticizmusa. In Dosztojevszkij, F. M., A félkegyelmű I-II. Ford.: Szabó Endre. Révai-kiadás. (Dosztojevszkij összes munkái XVI-XVII.) 1-16.

Ritoók Emma (1929). Előszó. In Dosztojevszkij, F. M., A kamasz I-IV. Ford.: Szabó Endre. Révai-kiadás. (Dosztojevszkij összes munkái XVIII-XXI.) 1-13. 
${ }^{15}$ A Dosztojevszkij-összes kiadástörténetének érdekes mozzanata az a kiadói döntés, miszerint több változatban is megjelentetik a sorozatot. Az 1921-ben indított széria feltehetően a középréteget célozta meg, a formátumát tekintve visszafogottabb, mint a későbbi, 1929-es kiadás, amely az exkluzív forma mellett több kötetet is tartalmazott, azonban terjedelmi okok miatt erre részletesebben nem térek ki.

${ }^{16}$ A budapesti könyvkereskedés 1869-ben alakult, és hamarosan meghonosította a tudományos antikváriumot, amely akkor még jóformán ismeretlen fogalom volt Magyarországon (bővebben ld. Újvári, 1929. 744-745.).

${ }^{18}$ Kiemelten foglalkozott az ifjúságnak szóló könyvek minőségét és jelentőségét érintő kérdésekkel. Mint a kiadó döntéshozója úgy vélte, hogy egy olyan irodalmi lapot kell létrehozni, amely erkölcsi és esztétikai iránymutatássá válhat a fiatalok számára. Így jött létre 1882-ben a Magyar Ifjúság címü hetilap. Ugyanebben az évben elindított egy másik nagy jelentőségü sorozatot Jó könyvek a magyar nép számára címmel, amelyet a kormány is támogatott. Trefort Ágoston kultuszminiszter, aki kész volt harcolni a ponyvairodalom térhódítása ellen, elfogadta Révay előterjesztését, részletes, mindenre kiterjedő programját (Révay, 1920. I/92.). A jelen távolságából szembetűnő az a - mai ember számára már-már ismeretlen - müködési elv, amelynek alapja a népnevelést érintő problémák felismerése és a szakemberek, illetve az állami döntéshozók közti párbeszéd, a szakmai javaslatok gyors és hatékony gyakorlati átültetéséről már nem is beszélve.

${ }^{19}$ Több ponton is összekapcsolódik ez a két sorozat, mivel a Dosztojevszkij-kötetek a Klasszikus Regénytár szerkesztési, előállítási és terjesztési folyamatai során szerzett tapasztalatokra épülnek, nem beszélve arról a szakmai gárdáról, melynek tagjai sok esetben mindkét sorozat létrehozásában közremüködtek.

${ }^{20}$ Schöpflin Aladár így emlékszik vissza a sorozatra: „Már a huszadik század első éveire esik a magyar irodalmi müveltség szempontjából nagy jelentőségü Klasszikus Regénytár kiadása. Ez akkor nem bizonyult valami fényes üzletnek, akkor még a közönség nem volt hozzászokva Tolsztoj, Dosztojevszkij, Balzac, Flaubert s a többi nagy írók alkotásaihoz, de ma ennek a nagyobbrészt jó fordításokban, gondos és hozzáértő szerkesztés alatt megjelent vállalatnak a kötetei nagy értéket jelentenek s antikváriumi példányokban nagy áron kelnek el. Írók és olvasók legnagyobb része belőlük ismerte meg a világirodalom nagy regényíróit.” (Schöpflin, 1926) Ld. még Trócsányi, 1940. 443.

${ }^{21}$ A centenárium önmagában azért sem magyarázza Dosztojevszkij műveinek teljes kiadását, mert a nem kevésbé népszerü Flaubert-nek ugyancsak 1921-ben volt a századik évfordulója.

${ }^{22}$ Révay átalakította a könyvterjesztés korábbi formáit. Az ő nevéhez füződik a részletüzlet meghonosítása (1885-ben az Aufrecht és Goldschmid céggel együtt), a kiadók így kiadványaik legfőbb terjesztőivé válhattak. A részletfizetési és bizományi rendszer hamar általánossá vált és kedvező hatást gyakorolt a könyvkereskedelemre is (Kókay, 1997. 71.). Emellett a szépirodalmi sorozataival (így a Dosztojevszkij összes munkáival is) gazdagítani kívánta a magyar irodalmat (ld. pl. e tanulmány mottóját).

\section{Absztrakt}

Európai sajátosság, hogy a nagy válság-korszakokban mindig megnő a Dosztojevszkij-művek iránti érdeklődés. Nem volt ez másképp Magyarországon sem, hiszen az első világháború utáni időszakra, 1920-30-as évekre tehető az író népszerüségének a csúcsa. Vajon milyen egyedi folyamatok vezettek oda, hogy az orosz író ekkorra a magyar kultúra szerves részévé vált? Jelen tanulmány többek között erre a kérdésre keres választ, és arra vállalkozik, hogy egyrészről feltérképezze a magyar Dosztojevszkij-kultusz intézményi kereteit, másrészről bemutassa Révay Mór János népnevelő tevékenységét, amely nagyban hozzájárulhatott ahhoz, hogy a magyar olvasóközönség megismerje Dosztojevszkij életét és megértse irodalomtörténeti jelentőségét. 